\title{
THE ADMISSIBILITY OF EXTRA-CURIAL STATEMENTS BY A NON-TESTIFYING ACCUSED
}

Introduction

Section 219 of the Criminal Procedure Act 51 of 1977 determines that "no confession made by any person shall be admissible as evidence against another person". Section 219 deals with the situation where an accused has made a confession that also incriminates a co-accused. The parts which incriminate the co-accused are inadmissible. Even indirect usage of a confession against someone other than the declarant is prohibited (see $R v$ Baartman 19603 SA 535 (A); and S v Makeba 20032 SACR 128 (SCA)). Section 219 does not deal with the admissibility of statements that are considered to be vicariously made (see in this regard Du Toit et al Commentary on the Criminal Procedure Act Revision Service 39 (2008) 2470J).

The Constitutional Court recently dealt with the admissibility of extra-curial statements by a non-testifying accused that incriminate a co-accused in $S v$ Molimi (2008 2 SACR 76 (CC)). The case came before the Constitutional Court by way of an application for leave to appeal against the judgment and order of the Supreme Court of Appeal in S v Molimi (2006 2 SACR 8 (SCA)). For present purposes, the relevant facts are that the applicant, Mr Molimi, was accused 2 at trial. He was convicted on a number of accounts in the High Court ( $S$ v Mbambo Sifiso CC 165/01, 9 October 2003, unreported). Accused 2 was the manager of a Clicks Store when it was robbed during a routine money collection by Fidelity Guards. Accused 1 was arrested at the scene of the crime and Accused 3 was a former employee of Fidelity Guards who was arrested some two months later. The applicant was arrested the day after the robbery. He made no statements to the police and the case turned on the admissibility of statements made by accused 1 and 3 against the applicant.

Accused 1 made a statement to the police incriminating himself, the applicant, accused 3 and other alleged members of the group involved in the robbery. This statement contained details of the robbery and the way in which the cell-phones of the applicant and accused 1 were to be used during the robbery. The Constitutional Court found this statement to be a confession, since it established an "unequivocal acknowledgement of guilt" to the crime of robbery with aggravating circumstances (par [29]) and decided that the ban in section 219 of the Criminal Procedure Act 51 of 1977 "was in recognition of the prejudice to the accused presented by the admission of such evidence" and that this has now been fortified by the right 
to a fair trial enshrined in the Constitution (par [30]). The court therefore kept the rule against the admissibility of those parts of a confession by one accused that incriminates a co-accused intact and disallowed the confession of accused 1 as evidence against the applicant.

Accused 3 also made a statement to the police implicating himself, the applicant and accused 1. This statement described the planning of the robbery, with details about meetings between him, accused 1 and the applicant. The court found this statement to be an admission, since accused 3 did not play an active part in the robbery (par [32]). He could still have raised a defence of dissociation from the common design to rob Clicks. As far as the admissibility of admissions by one accused that incriminate, another is concerned, the court refrained from deciding on the "correctness or otherwise" of the approach stipulated by the Supreme Court of Appeal in $S v$ Ndhlovu (2002 2 SACR 325 (SCA)) and applied the principles in that case to conclude that the admission by accused 3 was inadmissible as evidence against the applicant (par [47]-[49]). The main reason for this was that the late admission of the evidence of the admission (hearsay) was prejudicial to the applicant and not in the interest of justice. It is submitted that the decision on this issue cannot be faulted and is clearly correct in view of the facts of the case.

Because the rest of the evidence, comprising of cell-phone records and other evidence that did not implicate the applicant directly, could not prove the applicant's guilt beyond a reasonable doubt, he was found not guilty. If the evidence of the confession and the admission (hearsay) had been admitted, a strong case would have been made out for his guilt.

The decision in $S v$ Ndhlovu (supra) enables those parts of an admission by an accused that incriminate a co-accused to be used against the coaccused if it is admitted in terms of section 3(1)(c) of the Law of Evidence Amendment Act 45 of 1988. In S v Ralukukwe (2006 2 SACR 394 (SCA)) the Supreme Court of Appeal succinctly explains that this is possible because the Criminal Procedure Act 51 of 1977, contains no section that prohibits the use of an admission by one accused against another (399i400c). An admission that constitutes hearsay evidence in terms of the Law of Evidence Amendment Act 45 of 1988 can therefore be used against a coaccused if it is admitted in terms of section 3(1) of that Act. A confession cannot be admitted against a co-accused because of the provisions of section 219 of the Criminal Procedure Act 51 of 1977 read with the preamble to the Law of Evidence Amendment Act 45 of 1988 ("subject to the provisions of any other law") and section 3(2) of the latter Act, which states: "The provisions of ss (1) shall not render admissible any evidence which is inadmissible on any ground other than that such evidence is hearsay evidence."

In $S v$ Molimi (supra) the amicus curiae firstly criticised the approach in $S$ $v$ Ndhlovu (supra) because allowing hearsay in terms of section 3(1)(c) of the Law of Evidence Amendment Act 45 of 1988 would infringe the right to challenge evidence, since there is no opportunity for cross-examination (par [46]). Subsection 35(3)(i) of the Constitution states that: "Every accused 
person has the right to a fair trial, which includes the right - ... (i) to adduce and challenge evidence; ... "In $S v$ Ndhlovu (supra) the Supreme Court of Appeal found that the right to challenge evidence does not necessarily encompass the right to cross-examine the original declarant (340f). The Bill of Rights does not therefore guarantee an accused the right to subject all evidence to cross-examination. In the case of hearsay, the accused can resist its admission and scrutinise its probative value, including its reliability (see from 337a where Cameron JA explains why the "scheme and formulation" of the relevant provisions of Act 45 of 1988 are in line with the Constitution). The Act takes proper account of the nature of criminal proceedings where the state bears the onus of proof. This will play an important role in the admission of hearsay and the weight a court gives to it. Cameron JA refers to $S v$ Ramavhale (1996 1 SACR 639 (A) 649d-e), where the Supreme Court of Appeal said that:

"[A] Judge should hesitate long in admitting or relying on hearsay evidence which plays a decisive or even significant part in convicting an accused, unless there are compelling justifications for doing so."

A court applying the provisions of the legislation, must further do everything to ensure respect for the accused's fundamental right to a fair trial as expounded in section 35(5) of the Constitution. A court is firstly "under a duty to prevent a witness heedlessly giving vent to hearsay evidence". The provisions of Act 45 of 1988 must further be explained to an unrepresented accused before it can be applied against him. Lastly, an accused cannot be ambushed by the late or unheralded admission of hearsay evidence. A court should timeously and clearly be asked to consider and rule on its admissibility. This cannot be done only at the end of the trial.

Cameron JA refers to a further consideration relevant to the constitutionality of the legislation, that is the fact that the admissibility of evidence is, in general, one of law and not discretion (339e-f). An appeal court is therefore fully entitled to overrule such a decision by a lower court if it is considered to be wrong.

In the final instance, Cameron JA finds the general approach of Act 45 of 1988 to be in keeping with developments in other democratic societies based on human dignity, equality and freedom. The Canadian Supreme Court's general criteria, for example, accord well with the overall scheme of section 3 of Act 45 of 1988.

It has previously been submitted that the approach in $S v$ Ndhlovu (supra) is constitutionally sound in this regard, and for current purposes this issue will therefore not be explored any further (see Naudé "'Testimonial' Hearsay and the Right to Challenge Evidence" 20063 SACJ 320).

A second point of criticism from the amicus curiae in $S v$ Molimi (supra) is based on the differential treatment of admissions and confessions by an accused as evidence against a co-accused (par 48). In terms of this argument, section 219A of the Criminal Procedure Act 51 of 1977 should be read narrowly "so as to exclude admissions being used against a coaccused in precisely the same way $s 219$ prohibits the admission of a 
confession against another accused". It was therefore contended that section 3(1)(c) of the Law of Evidence Amendment Act 45 of 1988 and the approach in $S \vee N d h l o v u$ (supra) discriminate against accused persons in contravention of section 9(1) of the Constitution. Subsection 9(1) states that: "Everyone is equal before the law and has the right to equal protection and benefit of the law." The Constitutional Court was not prepared to make a determination in this regard, since the equality challenge was raised for the first time before them (par [49]). In addition, the issue was not properly raised in argument before them.

While it is agreed with the amicus that there is discrimination between admissions and confessions as far as evidence against a co-accused is concerned, it is submitted that the discrimination lies not in the admissibility of admissions by a non-testifying accused as evidence against a coaccused, but in the inadmissibility of confessions that incriminate a coaccused. Because it is possible to allow admissions by a non-testifying accused that incriminate a co-accused, this should also be possible in the case of confessions. To substantiate this point of view, it is first of all necessary to submit that there should be no difference between admissions and confessions, when referring to the admissions and confessions in the above case.

\section{Differential treatment of admissions and confessions}

\section{General}

The artificial distinction drawn between admission and confession has been criticized for many reasons: the most important point of criticism being the difference in their requirements for admissibility (see Schwikkard in Woolman et al Constitutional Law of South Africa 2ed (Original Service: 1107) 52-31). In the case of admissions, the requirement of "freely and voluntarily" has a restricted meaning and an admission will be found to be involuntary only if it has been induced by a promise or threat from a person in authority (see s 219A of the Criminal Procedure Act 51 of 1977; and Schwikkard and Van der Merwe Principles of Evidence 2ed (2002) 299). Confessions, on the other hand, have to be made freely and voluntarily whilst the maker is in his or her sound and sober senses and without having been unduly influenced thereto (s 217(1) of the Criminal Procedure Act 51 of 1977). The requirement of undue influence is elastic and goes beyond the ambit of voluntariness, which is restricted to an inducement, threat or promise coming from a person in authority $(R \vee$ Barlin 1926 AD $459462-$ 463).

It is indeed difficult to see how this distinction can still be maintained in view of section 35(1)(c) of the Constitution. Restricting the meaning of "voluntary" in the case of admissions would be in conflict with the constitutional principle of due process of law and the right to a fair trial as expounded in section 35(3) of the Constitution (see generally Schwikkard 
and Van der Merwe par 16711 ; and Zeffertt, Paizes and St Q Skeen The South African Law of Evidence (2003) 432 and 448). This section contains the accused's pre-trial privilege against self-incrimination and provides that an arrested person shall have the right "not to be compelled to make any confession or admission that could be used in evidence against" him or her. Nothing in this section suggests that admissions and confessions should be treated differently and admissions are often just as damaging as confessions (see De Vos "Die Bekentenis Uit 'n Historiese en Regsvergelykende Perspektief" 19903 TSAR 380 389). This is probably why admissions are in practice also required to have been done freely and voluntarily and without any undue influence (Kriegler and Kruger Hiemstra Suid-Afrikaanse Strafproses 6ed (2002) 588). In S v Agnew (1996 2 SACR 535 (C)) Foxcroft $\mathrm{R}$ remarks that:

"The legal maxim at the root of the protection afforded to an accused person
in our common law is nemo tenetur se ipsum accusare (no one is bound to
incriminate himself). It was held in $R v$ Becker 1929 AD 167 at 171 , that
before Courts or juries convicted on the strength of a confession and evidence
aliunde, such a confession should be unequivocal, for to look upon anything
less as a confession and therefore equivalent to a plea of guilty 'would be
most dangerous'. An innocent person might be convicted on a statement
which did not truly amount to a confession. The protection for an accused
envisaged in this laudable approach has had curious - and probably
unintended - results. Damaging admissions have been admitted in many
cases on the basis of their not amounting in law to confessions, and the
protection proclaimed in the maxim has been considerably eroded. $R v$ Xulu
1956 (2) SA 288 (A) is a good example of a most incriminating admission
being treated as admissible because it did not constitute a confession, since
the explanation afforded by the accused did not negative all possible innocent
explanations ... If full effect is given to the maxim that no one should be
obliged to incriminate himself, then it is difficult to understand how
incriminating statements contained in confessions should be treated differently
from words amounting to admissions only ... There is much to be said for
removing the artificial distinction between incriminating statements contained
in confessions as opposed to admissions, and the Constitution may provide
the path to this removal" (538f-539i).

It is in fact often difficult to determine whether a statement amounts to an admission or whether it is a confession: even our highest courts sometimes differ on whether a statement is a confession or a mere admission (see $S v$ Molimi 20062 SACR 8 (SCA) and S v Molimi (supra)). They are excluded for the same basic reason: involuntary confessions and admissions are both potentially unreliable. Since admissions and confessions depend for their probative value on the credibility of their makers, they both fall within the definition of hearsay evidence (Du Toit 24-50J). The rationale for admitting hearsay of this type lies in the fact that a person would not generally admit something against his interest unless it was true. In $R v$ Evans (1993 25 CR $\left(4^{\text {th }}\right) 46$ (SCC)) the Canadian Supreme Court remarks:

"The rationale for admitting admissions has a different basis than other exceptions to the hearsay rule. Indeed, it is open to dispute whether the evidence is hearsay at all. The practical effect of this doctrinal distinction is that in lieu of seeking independent circumstantial guarantees of trustworthiness, it is sufficient that the evidence is tendered against a party. Its admissibility rests on the theory of the adversary system that what a party has 
previously stated can be admitted against the party in whose mouth it does not lie to complain of the unreliability of his or her own statements" (54).

Schwikkard and Van der Merwe point out that unreliability was never the only reason for the inadmissibility of involuntary admissions and confessions and the privilege against self-incrimination also played an important part in this regard (par 1711 ).

Kriegler and Kruger remark that it is ironic that a confession, the most reliable extra-curial statement, is inadmissible against a co-accused, but admissions, often containing exculpatory parts, are admissible (587). An accused that fully incriminates him through a confession has in principle far less to gain than an accused who partly incriminates himself and partly shifts blame to another accused. It is rather admissions of this nature that are potentially more unreliable (Hor "Co-accused Confessions: The Third Anniversary" 19968 Singapore Academy of LJ 323 329). When someone attempts to exculpate himself, "the danger of minimising self guilt and maximising the guilt of others" is ever present (Hor 19968 Singapore Academy of LJ 332). In the US Supreme Court case of Lee $v$ Illinois (476 US 530 (1986)), the dissenting Justices agreed that "accomplice confessions ordinarily are untrustworthy precisely because they are not unambiguously adverse to the penal interest of the declarant", but are rather attempts to minimize the declarant's culpability (552-553). (Confessions in this regard include admissions as understood in terms of South African law). In another US Supreme Court case (Williamson v US 512 US 594 (1994)), the court noted that:

"One of the most effective ways to lie is to mix falsehood with truth, especially truth that seems particularly persuasive because of its self-inculpatory nature" (599).

In the end a confession is merely a specific type of admission: one where the accused admits all the elements of the specific offence and there is no clear reason why admissions and confessions should be treated differently (Kriegler and Kruger 565 and 567; Zeffertt et al 429; and Du Toit et al 2451).

\section{Distinction between admission and confession in common law jurisdictions}

Other major common law jurisdictions do not draw any distinction between admissions and confessions. In England, section 82(1) of the Police and Criminal Evidence Act of 1984, determines that a confession "includes any statement wholly or partly adverse to the person who made it, whether made to a person in authority or not and whether made in words or otherwise ..." In terms of this broad definition a confession therefore refers to any statement in which a person amongst other things admits relevant matters that are adverse to him or her (Ozin, Norton and Spivey PACE A Practical Guide to the Police and Criminal Evidence Act 1984 (2006) 166; Munday Evidence 4ed (2007) 456; and Murphy Murphy on Evidence 10ed (2008) 303). Dennis (The Law of Evidence 3ed (2007)) notes in this regard: 
"Thus any incriminating statement falling short of a full acknowledgement of the commission of an offence is still treated as a confession for the purposes of the regulatory scheme established by PACE .... It follows that a mixed statement, consisting of partly incriminating and partly exculpatory elements, is also a 'confession' for the purposes of PACE ... However, to qualify as a confession a statement must be adverse to its maker at the time it is made" (209).

Under Canadian law, a confession is also seen as a type of admission and may either be a full admission of all the elements of the crime or an admission of one or more material facts tending to prove the guilt of the accused (Sopinka, Lederman and Bryant The Law of Evidence in Canada 2ed (1999) Ch 8; and Paciocco and Stuesser The Law of Evidence 4ed (2005) 139).

Subject to certain exceptions, it is seen as a constitutional error in the USA to use either admissions or confessions by a non-testifying accused that incriminate a co-accused by name or otherwise (Bruton $v$ US 391 US 123 (1968); Gray v Maryland 523 US 185 (1998); Lilly v Virginia 119 S.Ct. 1887 (1999); Mueller and Kirkpatrick Evidence 3ed (2003) 771; Gianelli Understanding Evidence 2ed (2006) 452; and Rosenberg "The future of codefendant confessions" 200030 Seton Hall L Rev 516). Such statements can only be allowed when they fall "within a firmly rooted hearsay exception" or if they contain "particularized guarantees of trustworthiness" (Ohio $v$ Roberts 448 US 56 (1980) 66). In terms of Crawford $v$ Washington 541 US 36 (2004), however, there is an absolute bar against the use of such statements when they are considered to be "testimonial". This basically means that admissions or confessions are inadmissible where they were made to police officials in the course of an investigation where the circumstances objectively indicate that the primary purpose of the investigation was to establish or prove past events potentially relevant to later criminal prosecution (Davis v Washington 126 S.Ct. 2266 (2006) par II fn 1). Statements would be non-testimonial when made in the course of police interrogation under circumstances objectively indicating that the primary purpose of interrogation is to enable police assistance to meet an ongoing emergency (see Ross "Crawford's Short-lived Revolution: How Davis v. Washington reins in Crawford's reach" (2007) 83 ND L Rev 387 for a recent discussion in this regard).

The approach in $S v$ Ndhlovu (supra) enables a court to admit extra-curial admissions by a non-testifying accused against a co-accused, and there is no apparent reason why confessions should be excluded from this discretion. Having said this, it is necessary to have a closer look at the reasons why extra-curial statements of a non-testifying accused are generally inadmissible against a co-accused, since such evidence will always have to be approached with caution. This is also important in view of the fact that the major common law jurisdictions still abide by the principle that prevents extra-curial admissions or confession by an accused from being admitted against a co-accused, in spite of the fact that they do not draw any distinction between admissions and confessions. 


\section{Basic reasons for the inadmissibility of extra- curial statements by a non-testifying accused}

\section{General}

The rationale for admitting extra-curial statements made by an accused against him or her, lies partly in the fact that a person would not admit something against interest unless it was true, and mostly in the fact that "a party can hardly complain that when he or she made the statement he or she was not on oath or did not have an opportunity to cross-examine him or herself" (Zeffertt et al 429). However, when an extra-curial statement by a non-testifying accused is to be used against a co-accused, those parts which incriminate the co-accused are not against the accused's interest, and the assumption of their likely truth does not therefore apply (Hor "Confession of a Co-accused" 19946 Singapore Academy of LJ 366 373). Hor notes:

"Conditions of custody and interrogation and the realisation that one is under serious suspicion of committing a crime is fertile ground for unreliable statements even against self, but more so against others. The countervailing guarantee of reliability which is thought to attend statements against the interest of the declarant is absent" (380).

In addition, the co-accused cannot use cross-examination to challenge the admissibility of a statement by another made out of court in his absence.

When a suspect makes a statement that not only incriminates himself, but also a co-conspirator, there is always the motive to curry favour with the authorities and shift blame to others. In Lee $v$ Illinois (supra) the US Supreme Court notes that a co-accused confession is presumptively unreliable because of the desire to "shift or spread blame, curry favour, avenge himself, or divert attention to another" (544-545).

Because there is a clear risk that the accused will have a motive for implicating his co-accused, this means that all the objections against accomplice evidence are applicable. The court should therefore approach such evidence with caution (Schwikkard and Van der Merwe par 3011 1; Zeffertt et al 801). This should especially be so when the prosecution seeks to introduce admissions as opposed to confessions.

\section{Less obvious reasons}

There are other less obvious factors that increase the risk of false statements (see generally Chojnacki, Cicchini and LT White "An empirical basis for the admission of expert testimony on false confessions" 20081 Ariz St LJ 1; and Wright "Let's Take Another Look at That: False Confessions, Interrogation, and the Case for Electronic Recording" 2007 (1) Idaho L Rev 251). It is a known fact that some confessions are, albeit voluntary, simply false. There is a substantial amount of research that shows a number of possible reasons why this is so (see generally Dennis 212-213, inter alia referring to Gudjonsson The Psychology of Interrogations, Confessions, and 
Testimony (2003)). People may confess to well publicised crime in order to gain notoriety or because they suffer from generalised guilt feelings or because they simply want to indulge in criminal fantasies.

Unreliability may also stem from the constitution of the suspect (see generally Munday 454). A person may, for example, be unusually suggestible. In this regard psychological research indicates that it is specifically the frightened and suggestible who are most likely to confess under the pressure of custodial interrogation (Dennis 196). A suspect may also be in a vulnerable frame of mind or impaired physical state while being interviewed or may actually be suffering from a mental illness or an identifiable personality disorder. Stress appears to be a key factor in many false confessions (Dennis 212). The theory of interrogative suggestibility, developed by Gudjonsson provides a possible explanation in this regard (Chapter 14). In terms of this theory, certain people have a psychological make-up that makes it difficult for them to resist the pressure of interrogation. When this pressure is increased in the case of serious crimes, such persons may be more willing to accept suggestions made by their interrogators, resulting in two possible types of false confessions: "coercedcompliant" confessions and "coerced-internalised" confessions. With the first type, the suspect may tell the police what they want to hear in order to please them or to obtain a short-term advantage. The confession is made without thinking of the consequences or the suspect believes that the record can be put right later. Usually the confession is retracted once the stress has gone. In Blackburn ([2005] 2 Cr.App.R. 30), the English Court of Appeal states that "coerced-compliant" confessions were a topic on which expert evidence was admissible and accepted the evidence of a forensic psychologist that coerced-compliant confessions might be made by normal persons not suffering from any personality disorder or abnormal suggestibility, but rendered compliant, in the face of aggressive questioning, by fatigue and vulnerability due to age and other factors (440). With the second type of confession a suspect temporarily believes that he is guilty of the crime to which he has confessed. Such confession may be the product of factors such as mental confusion, intoxication, bad memory, suggestibility, immaturity and generalised feelings of guilt.

Because the confession or admission of a non-testifying accused is the hearsay of an accomplice, and suspiciously unreliable when made to police officials in the course of an investigation, such statements are in most jurisdictions only exceptionally admissible and usually only where the police were not involved with the obtaining of such statements. It is necessary to have a closer look at some of these exceptions, since they would be very relevant when a court considers the admissibility of admissions and confessions in terms of section 3(1)(c) of the Law of Evidence Amendment Act 45 of 1988. 


\section{Exceptional admissibility of extra-curial statements by a non-testifying accused}

\section{Proof of innocence}

Under English law a confession (or admission) by an accused cannot be used against a co-accused. Subsection 76(1) of Police and Criminal Evidence Act of 1984, confirms the decisions in $R v$ Gunewardene ([1951] 2 All ER 290); and $R \vee$ Spinks ([1982] 1 All ER 587) by stating that: "In any proceedings a confession made by an accused person may be given in evidence against him in so far as it is relevant to any matter in issue in the proceedings and is not excluded by the court in pursuance of this section" (also see $R v$ Jefferson [1994] 1 All ER 270, CA; and $R v$ Hayter [2005] UKHL 6 in this regard). In terms of section 76A of the Police and Criminal Evidence Act of 1984 (inserted by s 128 of the Criminal Justice Act of 2003), it is, however, possible for an accused to use the confession of a co-accused to prove his innocence (see generally Hartshorne "Defensive Use of a Coaccused's Confession and the Criminal Justice Act 2003" 20048 Int' IJ Evidence \& Proof 165; Dennis 248; Hirst "Confessions as Proof on Innocence" (1998) CLJ 146; and Munday 486). Because such statements would be offered by an accused, their admission would in principle not implicate the right to challenge evidence (compare Chambers $v$ Mississippi 410 US 284 (1973)). In terms of South African law such statements will more than probably be treated as hearsay (see $S \vee$ Jeniker 19941 SACR 141 $(A))$.

\section{Indirect usage}

Although English law does not allow a confession (or admission) by an accused to be used against a co-accused, there are exceptions to this rule (see generally Dennis 215). Other than in South Africa, the indirect usage of a confession against a person other than the declarant is allowed. In $R v$ Hayter (supra) the House of Lords allowed the indirect implication of one accused by the confession of a co-accused. The House of Lords decided that a jury was entitled, in a joint trial of two or more defendants for a joint offence, to consider first the case in respect of accused one, which is solely based on his own out-of-court statement, and then to use their finding of accused one's guilt and the role he played as a fact to be used evidentially in respect of accused two. However, before convicting accused two, the jury will have to be told that they must be sufficiently sure of the truthfulness of accused one's confession to convict him solely on the strength of it (86), and when determining the case against accused two, they must entirely disregard everything said out of court by accused one which might otherwise be thought to incriminate accused two (see generally Dwyer "The Admissibility of a Confession Against a Co-defendant: $R v$ Hayter" (2005) 68 Mod L Rev 839; McGourlay "Is Criminal Practice Impervious to Logic?: $R v$ Hayter" (2006) 10 Int LJ Evidence \& Proof 128). 


\section{Cases of conspiracy or joint venture}

Another exception exists under English law in cases of conspiracy or joint venture where the doctrine of implied agency allows statements by one conspirator or joint venturer in furtherance of the common purpose to be admissible against other conspirators or joint venturers to prove the nature and scope of the common purpose, although not their participation in the conspiracy or joint venture (see Dennis 743; Tapper Cross and Tapper on Evidence 11ed (2007) 618; and $R v$ Devonport, Pirano, and White [1996] 1 Cr.App.R. 221). The statement must, however, be in furtherance of the conspiracy, meaning that the common purpose must therefore be ongoing at the time the statement is made. Statements made to the police about what was done, would therefore be excluded from this exception. Such statements are made after the fact and not in furtherance of the conspiracy (see Schwikkard and Van der Merwe 296; Du Toit et al 24-70 for a discussion in the South African context and the relevance of vicarious admissions). In this regard, the same basic principles apply under Canadian and American law, where they also abide by the principle that the confession or admission of one co-accused is not admissible against the other coaccused (see Paciocco and Stuesser 144; $R$ v Mapara [2005] SCC 23 for the position in Canada; and Mueller and Kirkpatrick 796; Gianelli 460 for the position in the USA).

\section{Statements made as part of spontaneous exclamations}

The dangers inherent in using the confession of a non-testifying accused against a co-accused would also be less where such statements were made as part of spontaneous exclamations (see US $v$ Vasquez 857 F.2d 857, 864 $\left(1^{\text {st }}\right.$ Cir.) 1988). If a sudden event had assumed such intensity and pressure that the exclamation can safely be regarded as a true reflection of what was actually happening, then it ought to be received (see generally Zeffertt et al 417; Schwikkard and Van der Merwe 270; Naudé "The Unco-operative Victim and the Admissibility of Evidence: Some Pointers from the USA" 2006 39 CILSA 450). In the USA such "spontaneous exclamations" are also known as "excited utterances" or "spontaneous declarations" (see generally Byrom "The Use of the Excited Utterance Hearsay Exception in the Prosecution of Domestic Violence Cases After Crawford v Washington" 2005 23 Rev Litig 409 413). The rationale behind the admissibility of such statements has often been criticised (Gianelli 472-473). It is based upon the declarant's lack of capacity to fabricate. Although such evidence is in principle hearsay, it is not custodial statements and the usual concerns in this regard would in most instances not be present. Hor (1994 6 Singapore Academy of LJ 391) argues that only pre-investigation statements of coaccused persons should be admissible, because custodial statements "are infected not only with the twin sources of hearsay and accomplice unreliability, but also with the dangers associated with reliance on custodial statements". 


\section{Interlocking confessions}

The interlocking character of an accused and a co-accused's confession could also provide more reliability than usual (see Parker $v$ Randolph 442 US 62 (1979); Cruz v New York 481 US 186 (1987) for examples in this regard). Where the confession of a non-testifying accused that incriminates a co-accused is fully confirmed by or completely interlocks with the confession of the incriminated co-accused, the usual stigma surrounding such evidence is substantially less. Cross-examination would in principle have little value here and since the incriminated accused has already been prejudiced by confessing his own guilt, the normal suspicions would be reduced, if not absent. However, there are many reasons why people confess and it is therefore impossible to state an absolute rule in this regard (see generally Lung "Parker v. Randolph: The Right of Confrontation and the Interlocking Confessions Doctrine" 198032 Hastings LJ 305; Krit "Sixth Amendment - confrontation and the use of interlocking confessions in joint trial" 198878 J Crim L \& Criminology 937; Jezer "The Right to Confrontation in Codefendant Confession Cases: Richardson v. Marsh and Cruz v New York" 1989 Cornell L Rev 712; and Graham "Accomplice Confessions and the Confrontation Clause: Crawford $v$ Washington Confronts Past Issues With a New Rule" 200532 Pepp L Rev 315).

\section{Confessions made to a friend}

Another exception should also apply to confessions made by one coaccused to a friend. Although such confessions that incriminate another accused would not necessarily be trustworthy, they in principle do not carry the same concerns as statements made to the police (see Mueller "Tales out of School - Spillover Confessions and Against-interest Statements Naming Others" (2001) 55 U Miami L Rev 929945 and 954). A court should therefore more readily admit such statements in the interest of justice.

\section{$5 \quad$ Conclusion and recommendations}

Dennis remarks about the usage of confessions made by a non-testifying accused against a co-accused that one should be sceptical of an evidential rule that excludes strong probative evidence (216). Such evidence should only be excluded if there is "a substantial risk that the evidence will be unreliable or its admission will imperil the moral or expressive authority of the verdict". It is submitted that this is a sound argument. If admissions made by a non-testifying accused that incriminate another accused can be admitted in terms of the Law of Evidence Amendment Act 45 of 1988, then this should even more so be possible in the case of confessions.

A court that has to decide about the admissibility of a confession by a non-testifying accused that incriminates a co-accused will clearly have difficult task, but it is submitted that section 3(1)(c) of the Law of Evidence Amendment Act 45 of 1988 provides adequate guidelines to ensure that the presumptive unreliability of such statements can effectively be dealt with. 
However, before a court can consider the admissibility of hearsay in terms of section 3(1)(c) of the Law of Evidence Amendment Act, it will have to ensure that the principles stated by Cameron JA in $S v$ Ndhlovu (supra) are strictly adhered to. It would be best to incorporate these principles in legislation and to make it compulsory that a court must timeously and clearly be asked to rule on the admissibility of hearsay. This should be done before the prosecution closes its case, in order for the accused to appreciate the full evidentiary ambit he or she faces.

BC Naudé

University of South Africa 